Article

\title{
Wing Geometric Morphometrics of Workers and Drones and Single Nucleotide Polymorphisms Provide Similar Genetic Structure in the Iberian Honey Bee (Apis mellifera iberiensis)
}

\author{
Dora Henriques ${ }^{1}$, Julio Chávez-Galarza ${ }^{1,2}{ }^{\circledR}$, Juliana S. G. Teixeira ${ }^{3}$, Helena Ferreira ${ }^{1} \oplus$, \\ Cátia J. Neves ${ }^{1}\left(\mathbb{D}\right.$, Tiago M. Francoy ${ }^{4}\left(\mathbb{D}\right.$ and M. Alice Pinto ${ }^{1, *(\mathbb{D})}$ \\ 1 Centro de Investigação de Montanha (CIMO), Instituto Politécnico de Bragança, Campus de Sta. Apolónia, \\ 5300-253 Bragança, Portugal; dorasmh@ipb.pt (D.H.); jchavez@undc.edu.pe (J.C.-G.); \\ helenamf93@gmail.com (H.F.); catia.jose7@gmail.com (C.J.N.) \\ 2 Escola de Agronomia, Universidad Nacional de Cañete, Urb. Rosa de Hualcará, Calle Canal Maria Angola \\ s/n, San Vicente de Cañete, Lima 15701, Peru \\ 3 Faculdade de Filosofia, Ciências e Letras de Ribeirão Preto, Universidade de São Paulo, Av Bandeirantes, \\ 3900, Ribeirão Preto 14040-900, Brazil; s.julianat@gmail.com \\ 4 Escola de Artes, Ciências e Humanidades, Universidade de São Paulo, Rua Arlindo Béttio, 1000, \\ São Paulo 03828-000, Brazil; tfrancoy@usp.br \\ * Correspondence: apinto@ipb.pt; Tel.: +351-273-303-389
}

Received: 21 December 2019; Accepted: 23 January 2020; Published: 30 January 2020

\begin{abstract}
Wing geometric morphometrics has been applied to honey bees (Apis mellifera) in identification of evolutionary lineages or subspecies and, to a lesser extent, in assessing genetic structure within subspecies. Due to bias in the production of sterile females (workers) in a colony, most studies have used workers leaving the males (drones) as a neglected group. However, considering their importance as reproductive individuals, the use of drones should be incorporated in these analyses in order to better understand diversity patterns and underlying evolutionary processes. Here, we assessed the usefulness of drone wings, as well as the power of wing geometric morphometrics, in capturing the signature of complex evolutionary processes by examining wing shape data, integrated with geographical information, from 711 colonies sampled across the entire distributional range of Apis mellifera iberiensis in Iberia. We compared the genetic patterns reconstructed from spatially-explicit shape variation extracted from wings of both sexes with that previously reported using 383 genome-wide SNPs (single nucleotide polymorphisms). Our results indicate that the spatial structure retrieved from wings of drones and workers was similar $(r=0.93)$ and congruent with that inferred from SNPs ( $r=0.90$ for drones; $r=0.87$ for workers), corroborating the clinal pattern that has been described for $A$. $m$. iberiensis using other genetic markers. In addition to showing that drone wings carry valuable genetic information, this study highlights the capability of wing geometric morphometrics in capturing complex genetic patterns, offering a reliable and low-cost alternative for preliminary estimation of population structure.
\end{abstract}

Keywords: Iberian honey bee; spatial population structure; spatial principal component analysis (sPCA); SNPs

\section{Introduction}

Morphological markers have long been used to understand the diversity of life and the relationships among different taxa [1]. However, with DNA-based technologies being increasingly affordable and 
accessible to laboratories with low budgets, molecular markers are overriding morphological markers to become the standard tool for interrogating organisms [2-5]. Compared with morphological markers, molecular markers provide higher taxonomic resolution, allow a deeper understanding of the evolutionary processes, are stable and detectable independently of growth, differentiation and development and are not confounded by the environment [4-6]. On the other hand, morphological markers are still less costly, easier to use, do not require sophisticated instruments and a high level of technical expertise [7,8]. Given these advantages, when morphological traits offer taxonomic resolution that goes beyond the species level allowing detection of fine genetic structure, they could be used to identify populations that can be later studied with molecular markers $[7,8]$.

Traditional morphological methods typically employ multivariate statistics to quantitative variables such as length, height and width of structures, distances between certain landmarks and sometimes angles and ratios $[1,9,10]$. However, these methods are not always efficient in describing all the features of the body structures and the information of shape and size can be difficult to disentangle [9-11]. These shortcomings can be surpassed by geometric morphometrics, an approach developed at the end of the 20th century $[1,9,10]$. Geometric morphometrics uses 2D or 3D coordinates of biologically definable points, called landmarks, that capture the geometry of the structure under scrutiny $[1,10]$. To disentangle shape and size information and to remove variation in translation and rotation of the targeted structures, the landmarks are superimposed in a common coordinate system $[1,9,10]$. Compared with traditional methods, geometric morphometrics is more flexible in data acquisition, is able to capture the geometry of morphological structures preserving this information throughout the analysis [1] and has a greater discriminating power (see [12-16]). These features have made geometric morphometrics a popular tool to investigating diversity patterns of many organisms (reviewed in Adams, et al. [1] and Tatsuta, et al. [11]), the western honey bee (Apis mellifera L.) is no exception [2,16-22].

The father of A. mellifera taxonomy and biogeography, Friedrich Ruttner [23], applied traditional morphometrics to 36 body size, pilosity, colouration, and wing venation traits to distinguish 24 subspecies collected from Africa, Europe, and the Middle East. Since the pioneer work of Ruttner [23], a wide array of molecular and morphological (including wing geometric morphometrics) markers has been used to identify and classify honey bee lineages and subspecies in both the native and introduced ranges $[2,3,17,18,21,22,24-31]$. The patterns obtained with the more recently developed wing geometric morphometrics approach have been largely consistent with those inferred from the traditional morphometry [2,16,22]. However, this has not always been the case. As an example, while Ruttner [23] placed the North African Apis mellifera intermissa and Apis mellifera sahariensis together with the European subspecies Apis mellifera mellifera and Apis mellifera iberiensis in the western European (M) lineage, later phylogeographic studies using nuclear DNA markers [22,32-34] and geometric morphometrics [22] re-arranged the African (A) lineage to include North African together with sub-Saharan subspecies.

Wing geometric morphometrics has proved capable of identifying lineages, subspecies, and even hybrids [2,16-22]. However, whether this method is equally capable of capturing genetic structure within a subspecies range has yet to be fully assessed. The honey bee subspecies that evolved in the Iberian Peninsula, A. m. iberiensis, offers a powerful model system to address this issue for two main reasons. First, the Iberian honey bee exhibits a complex phylogeographic pattern which, contrarily to other subspecies, has been largely resilient to confounding beekeeper-mediated processes [35]. Second, no other subspecies has been as thoroughly surveyed as the Iberian honey bee. In the last 40 years, thousands of colonies sampled from across the entire Iberia have been interrogated using a battery of markers, including morphology [22,25,36], allozymes [25,37], mitochondrial DNA [25,32,38-48], microsatellites [22,32,39,49-51], SNPs [35,52], and even whole genomes [53]. Early surveys using traditional morphometrics and allozymes revealed existence of a smooth gradient extending from France to North Africa, with Iberian populations showing intermediate phenotypes [25,37]. However, this pattern was not supported by maternally-inherited mitochondrial polymorphisms which formed 
not a smooth but a steep northeast-southwest cline of highly divergent haplotypes of western European and African ancestry in Iberia [25,32,35,38-41]. Adding to the complexity, microsatellites [22,32,49,51] and wing geometric morphometrics data [22] did not capture either the Iberian northeast-southwest cline or the smooth gradient extending from north Africa to France, but instead a sharp disruption in genetic variation between the two continents. The lack of genetic structure reported from wing shape [22] and microsatellite [22,32,49,51] data contrasts with genome-wide SNPs [35] and even whole genomes [53], which recovered the clinal pattern reported earlier.

The vast amount of knowledge generated by all those works enables unprecedented comparisons between markers as to their power in retrieving complex diversity patterns. Using the Iberian honey bee as a model system, the first goal of this study was to assess the efficiency of geometric morphometrics in capturing genetic structure within a subspecies range. To that end, a comprehensive geometric morphometrics dataset was integrated with geographical information to disentangle global structure from local structure and random noise. If geometric morphometrics would prove efficient in describing structure in a subspecies with a complex phylogeographic pattern, it could be used as a low-cost alternative for preliminary genetic surveys.

Geometric morphometrics can be applied to different parts of an organism, but wings, mainly from females, have been the major target in Diptera and Hymenoptera [11]. Insect wings are well suited to geometric morphometrics analysis because of the high heritability of shape $[11,54]$ and of the approximate two-dimensional structure, which reduces digitizing errors [55]. A number of studies have applied geometric morphometrics to investigate wing sexual dimorphism in social hymenopterans [56-58], which tends to be pronounced in this group of insects [59] due to the haplodiploid sex-determination system. In honey bees, geometric morphometrics surveys have typically been applied to the forewings of workers [2,16-22] since drones usually exhibit a higher number of wing venation anomalies due to their haploid condition [60]. Besides, drones are only present in the colony during certain periods of the year, making harder their sampling. Whether the forewings of drones carry information similar to that of forewings of workers and whether this information is able to retrieve complex phylogeographic patterns is unclear. Hence, the second goal of this study was to assess the degree of similarity between structures inferred from the forewings of both sexes.

To achieve these goals, we used a geometrics morphometrics approach to examine the forewing shapes of multiple drones and workers belonging to 711 georeferenced colonies of A. m. iberiensis sampled across three north-south Iberian transects. The 711 colonies were previously analysed with 383 genome-wide SNPs genotyped in drones, which showed the existence of a strong global structure formed by two genetic clusters [35]. Using the spatially-explicit wing shape data obtained for drones and workers and the SNP data genotyped by Chávez-Galarza, et al. [35], we addressed the following questions: (i) Is the wing geometric morphometrics approach able to detect genetic structure in the Iberian honey bee? (ii) Are the results obtained with wing geometric morphometrics concordant with those inferred from SNP data? (iii) Are the patterns inferred from the forewings of drones and workers congruent? By answering these questions, we expect to provide new insights into the usefulness of drone wings and the power of geometric morphometrics in detecting genetic structure in honey bee populations.

\section{Materials and Methods}

\subsection{Sampling}

Samples of drones and workers were collected in 2010 from 711 colonies distributed in the Iberian Peninsula along three transects (Figure 1): the Atlantic transect (AT; 8 sites), the Central transect (CT; 9 sites), and the Mediterranean transect (MT; 6 sites). Each of the 23 sites was represented by 10 georeferenced apiaries. Drones and workers were collected from the inner frames of three hives per apiary and stored in absolute ethanol until subsequent analyses. 


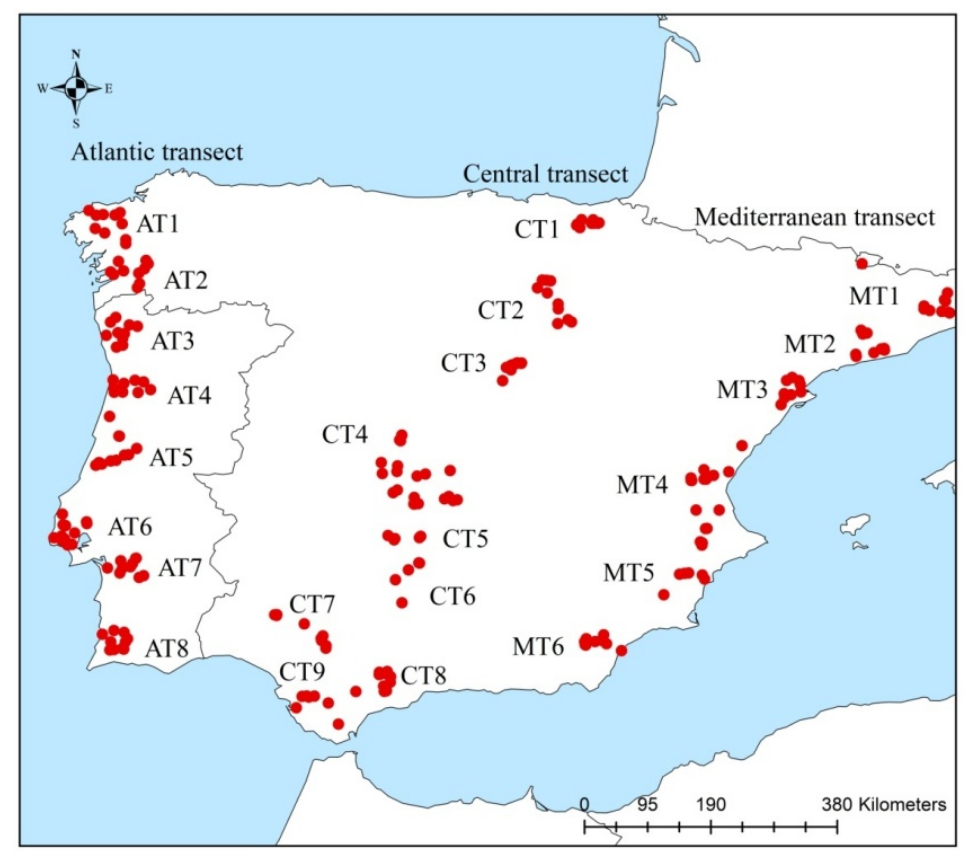

Figure 1. Geographical location of 711 colonies sampled in the Iberian Peninsula.

\subsection{Geometric Morphometrics Analysis}

For most of the 711 colonies, the right forewing was detached from five drones and five workers, placed between slides and photographed with a digital camera attached to a stereomicroscope. Specifically, for 56 colonies (37 drones and 19 workers) the number of detached forewings was lower than five (see Table S1 for details). In order to capture the Cartesian coordinates of the landmarks, a tps file was constructed from the images using tpsUtil v1.76 [61]. The tps file was used by tpsDig v2.17 [62] where 19 homologous landmarks were manually plotted across the forewing venation, following the order displayed in Figure 2. Wings missing one or more landmarks were removed from the dataset leading to a total of 3262 drone (709 colonies) and 3511 worker (710 colonies) forewings for downstream analyses (Table S1). The landmark coordinates obtained from tpsDig were used as input in MorphoJ v1.06a [63]. The Cartesian coordinates of the specimens were then aligned to remove variations in size, position, and orientation using the generalized Procrustes superimposition method [64]. The mean values of the landmark coordinates obtained from multiple wings per colony ( 5 wings/per colony for $71.7 \%$ of drones and $95.6 \%$ workers; Table S1) were used to generate a covariance matrix for downstream analyses. Pairwise Procrustes distances among populations (sites) were obtained through the canonical variate analysis (CVA). Pearson correlation coefficient (r) values were computed in R 3.6.0 [65] using as input data the Procrustes distances, obtained from drones and workers' wing shapes (Table S2), and the $\mathrm{F}_{\mathrm{ST}}$ values (Table S3) obtained from SNPs genotyped in drones by Chávez-Galarza, et al. [35]. 


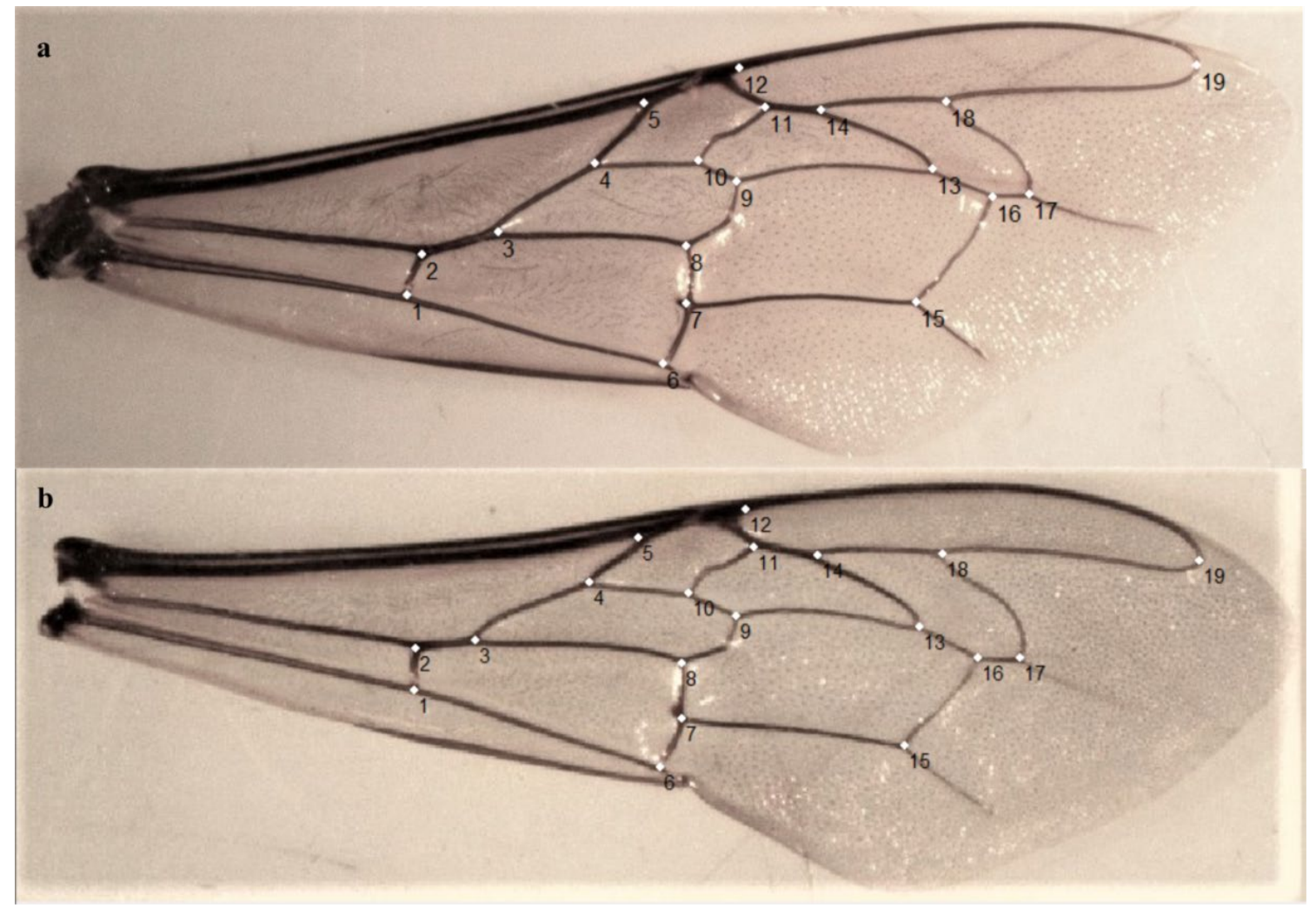

Figure 2. The 19 landmarks placed on the vein junctions of the right (a) drone and (b) worker forewings.

\subsection{Estimation of Spatial Structure}

Spatial structure was inferred from drone and worker forewing shapes using the model-free multivariate spatial principal component analysis (sPCA). The sPCA of the drone SNPs was performed in the software package adegenet [66], using the K-nearest neighbours to model the spatial connectivity among individuals (see Chávez-Galarza, et al. [35] for further details). For wing geometric morphometrics data, the sPCA was carried out following the same parameters as for SNP data [35], but using the ade4 software package [67]. The morphometric input data used in the sPCA was constructed from the average distances calculated between proximal landmarks for each colony.

The sPCA is a modification of PCA and considers the genetic variance of individuals or populations together with their spatial autocorrelation measured by Moran's I, which ranges from -1 to 1 [68]. To calculate Moran's I, the genetic variance observed at a given location is compared with those at neighbouring sites [69]. Highly positive Moran's I values indicate the presence of global structure, which occurs when each sampling location is genetically closer to neighbours than randomly chosen locations, as it happens in the presence of patches, clines or intermediate states. On the other hand, highly negative Moran's I values indicate the existence of a stronger genetic differentiation among neighbours than randomly-chosen locations, which indicates local structure. The Moran's I values were calculated considering the component with the highest eigenvalue. To evaluate the consistency of the detected geographical structures and the statistical significance for global and local structures, Monte Carlo simulations were implemented using 10,000 permutations, meaning that the significance threshold level is set at $1 \times 10^{-4}$. This test validates whether genetic variance is distributed at random on the connection network (null hypothesis), or display global or local spatial structure (alternative hypothesis). In each permutation, the maximum of the mean of determination coefficient $(\max (t))$ is computed. The coefficient of determination is estimated by linear regression between the matrix of allelic frequencies or morphometric measures and the eigen analysis of spatial connectivity among individuals. If the observed $\max (\mathrm{t})$ associated with the local or global structure is different from most simulated values and the $P$-value $\leq 1 \times 10^{-4}$, the spatial distribution of the genetic variance is not 
random and the null hypothesis can be rejected. Spatial structure inferred from drone SNPs and wing geometric morphometrics data of both drones and workers were compared through the Pearson correlation coefficient (r) calculated in R 3.6.0 [65] using the first component of the sPCA.

\section{Results}

The canonical variate analysis (CVA) of drone and worker forewing shapes showed no clear structure in the Iberian honey bee (Figure 3). Pairwise Procrustes distances, which indicate the degree of differentiation among populations (sites) in wing shapes, were low and similar in the two sexes (Table S2). Procrustes distance values ranged from 0.0037 to 0.0116 , in drones, and 0.0030 to 0.0112 , in workers. The most divergent populations originated from the latitudinal extremes of the Iberian honey bee range, namely: MT2 and AT6, for drones (Procrustes distance $=0.0116$ ), and CT1 and AT7, for workers (Procrustes distance $=0.0112$; Table S2). Pairwise Procrustes distances of drones were moderate but significantly correlated with those of workers $\left(\mathrm{r}=0.55, P\right.$-value $\left.<2.2 \times 10^{-16}\right)$. Similar correlations were obtained between $\mathrm{F}_{\mathrm{ST}}$ values inferred from SNPs (Table S3) and Procrustes distances (Table S2) inferred from wing shapes of drones $\left(\mathrm{r}=0.50, P\right.$-value $\left.<2.2 \times 10^{-16}\right)$ and workers $(\mathrm{r}=0.58$, $P$-value $\left.<2.2 \times 10^{-16}\right)$.
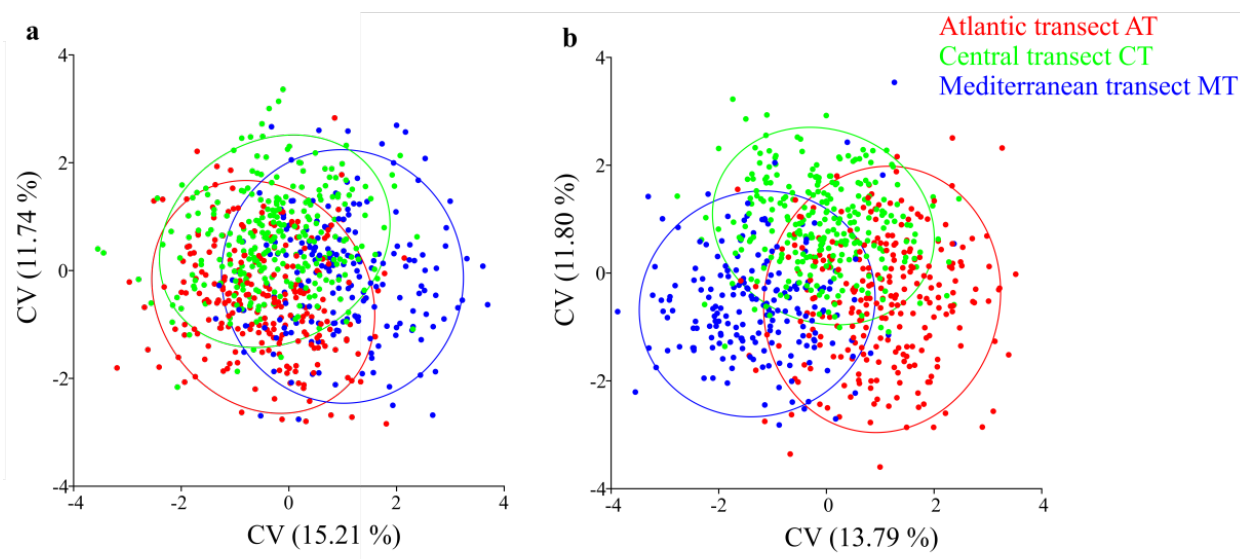

Figure 3. Scatterplots of individual scores from the canonical variant (CVA) analysis of (a) drone and (b) worker wing landmarks of the Iberian honey bee. Each dot represents a colony.

The patterns of forewing shape variation of both sexes were further examined using a spatially explicit approach. The first global score (the axis with most positive eigenvalue) for drones and workers was associated with moderate autocorrelations (Moran's I $=0.186$ and Moran's I $=0.304$, respectively). On the other hand, the first local score (the axis most negative eigenvalue) was low either for drones (Moran's I $=-0.0178$ ) or workers (Moran's I $=-0.0208$ ). The interpolation of the first global score for both sexes detected a well-defined cline dividing Iberia along a northeast-southwest axis (Figure $4 a, b$ ), being the southwestern individuals (large black squares) the most differentiated from the northeastern individuals (large white squares). The global structure retrieved from wing geometric morphometric data was concordant with that obtained from SNPs genotyped in drones by Chávez-Galarza, et al. [35] (Figure 4c). 

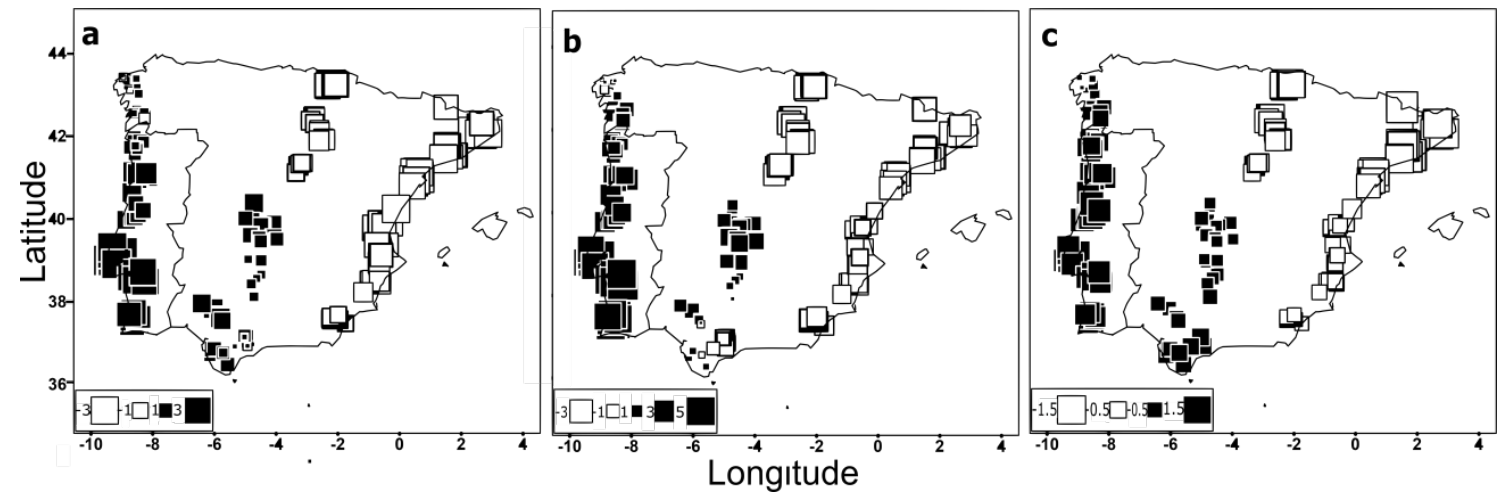

Figure 4. Global structure displayed by the 711 colonies (from 23 sampling sites located in the Atlantic, Central, and Mediterranean transects) after the spatial principal component analysis (sPCA). Global scores (first principal component) obtained from (a) wing geometric morphometrics of drones, (b) wing geometric morphometrics of workers, and (c) SNPs genotyped in drones by Chávez-Galarza, et al. [35]. Squares represent population scores and are spatially arranged according to the geographical coordinates of the colonies. Large black squares indicate colonies well differentiated from those denoted by large white squares whereas small squares indicate a lower degree of differentiation.

As reported in Chávez-Galarza, et al. [35] for SNPs, Monte Carlo simulations using wing shape data confirmed the existence of global structure in both drones $\left(\max (t)=0.01627, P\right.$-value $<1 \times 10^{-4}$; Figure 5a) and workers $\left(\max (t)=0.0303, P\right.$-value $<1 \times 10^{-4}$; Figure $\left.5 b\right)$. In contrast, there was no statistical evidence of local structure for either drones $(\max (t)=0.00359, P$-value $=0.8670 ;$ Figure $5 c)$ or workers $(\max (t)=0.00435, P$-value $=0.2772$; Figure $5 d)$.
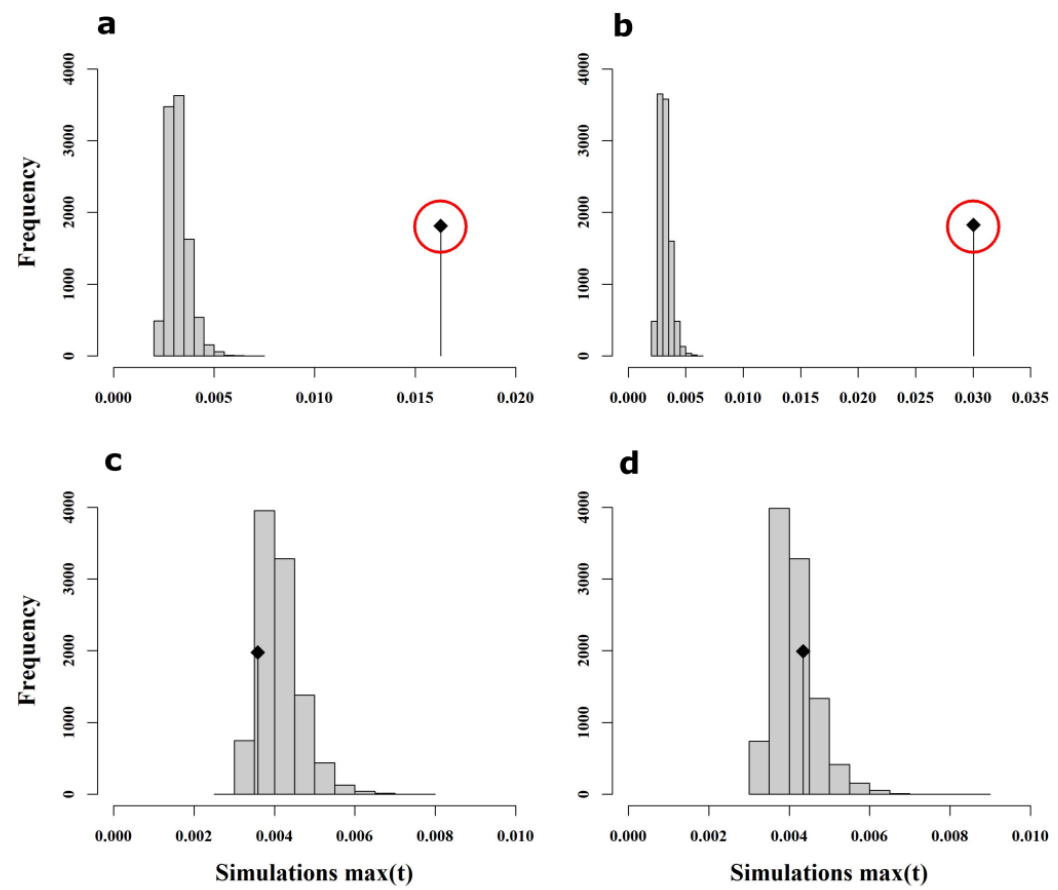

Figure 5. Results of Monte Carlo simulations using wing shape data. The $\mathrm{x}$-axis represents $\max (\mathrm{t})$ calculated in each permutation whereas the $y$-axis represents the frequency of each max(t) class. The observed $\max (\mathrm{t})$ value is represented by the vertical black line with the black square on top. Monte Carlo simulations support the existence of global structure for both sexes (a-drones; b-workers) but not local structure (c-drones; d-workers), as indicated by the location of the observed max $(\mathrm{t})$ value outside $(\mathbf{a}, \mathbf{b})$ or inside $(\mathbf{c}, \mathbf{d})$ the histogram of simulated values. Outside locations of observed $\max (\mathrm{t})$ values specify statistical significance (indicated by the red circle). 
Spatial patterns inferred from wing shape data of drones and workers and from SNPs (reported in Chávez-Galarza, et al. [35]) were compared through the correlation coefficient (r) using the first component of the sPCA (Figure 4). Interestingly, high correlation values were obtained not only between wing shapes of both sexes $\left(r=0.93, P\right.$-value $\left.<2.2 \times 10^{-16}\right)$ but also between SNPs and wing shapes of drones $\left(\mathrm{r}=0.90 ; P\right.$-value $\left.<2.2 \times 10^{-16}\right)$ and workers $\left(\mathrm{r}=0.87 ; P\right.$-value $\left.<2.2 \times 10^{-16}\right)$, suggesting that the spatial analysis is more powerful in detecting population structure as compared to the traditional CVA and Procrustes distances.

\section{Discussion}

The landmark-based geometric morphometrics is acknowledge as the most rigorous and powerful morphometric technique currently available. It has been applied to a variety of structures (e.g., wings, shells, cranial bones, mandibles, premaxilla) and organisms (from insects to mammals) to describe interand intra-specific variation and underlying evolutionary processes [70-78]. In A. mellifera, geometric morphometrics of wing vein junctions has been used to discriminate amongst evolutionary lineages and subspecies $[2,16,18,19,21]$, but not to detect genetic structure within subspecies. Herein, we elected A. $m$. iberiensis as the model system to unequivocally show, for the first time in A. mellifera, the power of wing geometric morphometrics in retrieving complex phylogeographic patterns, particularly when wing shape data is analysed using a spatially explicit framework.

We first analysed the wing shape data obtained from drones and workers using traditional multivariate statistics. This approach was unable to reveal a clear structure within the Iberian honey bee range (Figure 3), congruent with earlier surveys of microsatellites [22,32,39,49-51] and wing geometric morphometrics [22]. However, when the wing shape data were analysed using a spatially-explicit framework, we found statistical support for the presence of global structure $\left(P\right.$-value $\left.<1 \times 10^{-4}\right)$. Interpolation of the first global scores, computed from variations carried by the wing landmarks of both sexes, was able to unambiguously retrieve the clinal shape of variation (Figure 4) with a striking degree of overlap with that inferred from mtDNA and genome-wide SNPs [25,32,35,38-48,52]. The lack of genetic structure reported in previous works [22,51] has been explained by recent beekeepers-mediated gene flow associated with mobile beekeeping, erasing any signal of clinal variation [51]. However, these works missed the geographical breadth and the spatially-based statistical power needed to detect the cline reported here and in other studies using molecular markers [25,32,35,38-48,52]. The integration of geographical information with geometric morphometrics methods has also been used with success in other insects [71,72], further supporting the power of the spatial approach to uncover population structure.

Arias, et al. [25] nearly approached the Iberian cline using traditional morphometry on numerous traits measured in workers. However, wing geometric morphometrics has several practical advantages over traditional morphometrics. While Arias, et al. [25] needed to examine 23 characters from different parts of the honey bee body, wing geometric morphometrics only requires detachment of forewings. Due to their near two-dimensional structure, wings can then be easily mounted and photographed, or even digitalized, and stored forever for future analyses. Analysis of wing images is easier and less time consuming than measuring body size, pilosity, colouration, and lengths and angles of wing veins. The most labour-intensive step in geometric morphometrics is to manually plot the 19 landmarks in wings, but this task is expected to be fully automated in the near future.

This study revealed a high consistency between wing morphology and genome-wide SNPs, with correlation values of 0.87 (workers' wing shape versus SNPs) and 0.90 (drones' wing shape versus SNPs) for the spatial genetic patterns inferred from both markers. The ability of wing traits to capture a genetic pattern so strikingly similar to that inferred from hundreds of molecular loci spread across the 16 honey bee chromosomes [35,52] could be explained by a high heritability and a polygenic nature of wing shape. While the genetic basis of forewing venation is virtually unknown in most insects, including honey bees, it is likely that wing shape has a strong genetic control, as suggested by this 
and other studies which have also reported concordance between wing morphology and molecular markers, such as mtDNA and microsatellites [78-83].

In Hymenoptera, wing geometric morphometrics has been used to examine sexual dimorphism [56-58]. While Pretorius [57] found a good correlation $(r=0.47)$ between wing shapes of males and females in several species of Tachyspex, Abbasi [56] reported a weak correlation $(r=0.16)$ in three species of Polistes. Here, we showed, for the first time in A. mellifera, that the genetic information carried by drone wings for identifying genetic structure is similar to that of workers, the commonly used form in diversity studies [2,16-22]. Furthermore, the spatial structure inferred from SNPs was more similar to that inferred from drone wings $(r=0.90)$ than to that of workers $(r=0.87)$. This finding makes sense since the 383 genome-wide SNPs were genotyped in drones [35]. Despite the potential usefulness of drone wings for carrying out diversity studies, workers have been preferred because they are always available in a colony and they typically display a lower number of wing venation anomalies. In this study, a total of 206 drones and 14 workers were eliminated from the initial dataset because of missing landmarks. Drones are haploid, allowing more frequent phenotypic expression of deleterious alleles, which were identified here as missing landmarks.

In this study, we examined concordance between genetic patterns captured by different genetic markers and sexes in a honey bees subspecies that is free of introgression from commercial strains $[35,38,43,45,46,49,52,53]$ and that has been shaped by complex evolutionary processes [35,52,53], involving recurrent cycles of contraction, expansion, admixture, and adaptation, typical of long-term glacial refugia. Our findings suggest that geometric morphometrics of worker as well as drone forewings can be used reliably for detecting intra-subspecific genetic structure. The question whether the observed relationships are unique for this particular honey bee subspecies or represent a more general pattern deserves to be further investigated.

\section{Conclusions}

This study highlights the power of wing geometric morphometrics in capturing genetic structure within honey bee subspecies, especially when shape data is integrated with geographical information and analysed using spatial statistics. Spatial analysis of wing shape variation was able to detect a well-defined cline that bisects Iberia along a northeast-southwest axis, a pattern that remarkably parallels that of genome-wide SNPs. Moreover, in spite of the haploid nature of drones, allowing more frequent phenotypic expression of wing abnormalities, the genetic structure retrieved from drones was similar to that of workers, suggesting that drone forewings carry usable genetic information for diversity studies. Geometric morphometrics has the benefit over molecular methods of being cheaper and easier to use [7,18], offering a preliminary or complementary tool for identifying honey bee lineages, subspecies, and even detecting intra-subspecies structure [2,16-22].

Supplementary Materials: The following are available online at http://www.mdpi.com/2075-4450/11/2/89/s1, Table S1: Number of forewings detached from drones (1) and workers (4), number of forewings discarded for drones (2) and workers (5) due to missing landmarks, and final number of forewings analysed for drones (3) and workers (6). Table S2: Procrustes distances inferred from wing shape data of workers (below diagonal) and drones (above diagonal) obtained for the 23 populations (sites). The values marked in bold are significant after sequential Bonferroni correction. Table S3: F $_{\text {ST }}$ distances calculated using SNP data from Chávez-Galarza, et al. [35]. The values marked in bold are significant after sequential Bonferroni correction.

Author Contributions: Conceptualization, M.A.P. and T.M.F.; methodology, M.A.P., T.M.F., J.C.-G.; Formal analysis, J.C.-G., H.F., J.S.G.T., C.J.N. and D.H.; writing—original draft preparation, D.H. and M.A.P.; writing-review and editing, M.A.P. and D.H.; supervision, M.A.P.; project administration, M.A.P.; funding acquisition, M.A.P. All authors have read and agreed to the published version of the manuscript.

Funding: This research was funded by the program COMPETE 2020-POCI (Programa Operacional para a Competividade e Internacionalização) and by Portuguese funds through FCT (Fundação para a Ciência e a Tecnologia) in the framework of the project BeeHappy (POCI-01-0145-FEDER-029871). FAPESP (Fundação de Amparo à Pesquisa do Estado de São Paulo) provided funds for TMF (2011/07857-9) and JSGT (2011/02434-2). 
Acknowledgments: We are indebted to numerous beekeepers and technicians of beekeepers' associations and of government institutions for assistance with the honey bee sampling. Special thanks are due to Antonio G. Pajuelo for providing contacts of Spanish beekeepers; to Irene Muñoz, Andreia Brandão, Inês Moura and Margarida Neto for helping in the field work; to Pilar de da Rúa and Irene Muñoz for helping contacting beekeepers in Spain.

Conflicts of Interest: The authors declare no conflict of interest.

\section{References}

1. Adams, D.C.; Rohlf, F.J.; Slice, D.E. Geometric morphometrics: Ten years of progress following the 'revolution'. Ital. J. Zool. 2004, 71, 5-16. [CrossRef]

2. Oleksa, A.; Tofilski, A. Wing geometric morphometrics and microsatellite analysis provide similar discrimination of honey bee subspecies. Apidologie 2015, 46, 49-60. [CrossRef]

3. Meixner, M.D.; Pinto, M.A.; Bouga, M.; Kryger, P.; Ivanova, E.; Fuchs, S. Standard methods for characterising subspecies and ecotypes of Apis mellifera. J. Apic. Res. 2013, 52, 1-28. [CrossRef]

4. Morin, P.A.; Luikart, G.; Wayne, R.K. SNPs in Ecology, Evolution and Conservation. Trends Ecol. Evol. 2004, 19, 208-216. [CrossRef]

5. Agarwal, M.; Shrivastava, N.; Padh, H. Advances in molecular marker techniques and their applications in plant sciences. Plant Cell Rep. 2008, 27, 617-631. [CrossRef]

6. Muñoz, I.; Henriques, D.; Jara, L.; Johnston, J.S.; Chávez-Galarza, J.; De la Rúa, P.; Pinto, M.A. SNP s selected by information content outperform randomly selected microsatellite loci for delineating genetic identification and introgression in the endangered dark European honeybee (Apis mellifera mellifera). Mol. Ecol. Resour. 2017, 17, 783-795. [CrossRef]

7. Ortego, J.; Aguirre, M.P.; Cordero, P.J. Genetic and morphological divergence at different spatiotemporal scales in the grasshopper Mioscirtus wagneri (Orthoptera: Acrididae). J. Insect Conserv. 2012, 16, 103-110. [CrossRef]

8. Patterson, J.; Schofield, C. Preliminary study of wing morphometry in relation to tsetse population genetics: Research in action. S. Afr. J. Sci. 2005, 101, 132-134.

9. Rohlf, F.J.; Marcus, L.F. A revolution morphometrics. Trends Ecol. Evol. 1993, 8, 129-132. [CrossRef]

10. Zelditch, M.L.; Swiderski, D.L.; Sheets, H.D. Geometric Morphometrics for Biologists: A Primer; Elsevier Science Publishing Co Inc.: San Diego, CA, USA, 2012.

11. Tatsuta, H.; Takahashi, K.H.; Sakamaki, Y. Geometric morphometrics in entomology: Basics and applications. Entomol. Sci. 2018, 21, 164-184. [CrossRef]

12. Bernal, V. Size and shape analysis of human molars: Comparing traditional and geometric morphometric techniques. Homo 2007, 58, 279-296. [CrossRef] [PubMed]

13. Maderbacher, M.; Bauer, C.; Herler, J.; Postl, L.; Makasa, L.; Sturmbauer, C. Assessment of traditional versus geometric morphometrics for discriminating populations of the Tropheus moorii species complex (Teleostei: Cichlidae), a Lake Tanganyika model for allopatric speciation. J. Zool. Syst. Evol. Res. 2008, 46, 153-161. [CrossRef]

14. Viscosi, V.; Lepais, O.; Gerber, S.; Fortini, P. Leaf morphological analyses in four European oak species (Quercus) and their hybrids: A comparison of traditional and geometric morphometric methods. Plant Biosyst. 2009, 143, 564-574. [CrossRef]

15. Parsons, K.J.; Robinson, B.W.; Hrbek, T. Getting into shape: An empirical comparison of traditional truss-based morphometric methods with a newer geometric method applied to New World cichlids. Environ. Biol. Fishes 2003, 67, 417-431. [CrossRef]

16. Tofilski, A. Using geometric morphometrics and standard morphometry to discriminate three honeybee subspecies. Apidologie 2008, 39, 558-563. [CrossRef]

17. Francoy, T.M.; Wittmann, D.; Steinhage, V.; Drauschke, M.; Müller, S.; Cunha, D.; Nascimento, A.; Figueiredo, V.; Simões, Z.; De Jong, D. Morphometric and genetic changes in a population of Apis mellifera after 34 years of Africanization. Genet. Mol. Res. 2009, 8, 709-717. [CrossRef]

18. Francoy, T.M.; Wittmann, D.; Drauschke, M.; Müller, S.; Steinhage, V.; Bezerra-Laure, M.A.; De Jong, D.; Gonçalves, L.S. Identification of Africanized honey bees through wing morphometrics: Two fast and efficient procedures. Apidologie 2008, 39, 488-494. [CrossRef] 
19. Barour, C.; Baylac, M. Geometric morphometric discrimination of the three African honeybee subspecies Apis mellifera intermissa, A. m. sahariensis and A. m. capensis (Hymenoptera, Apidae): Fore wing and hind wing landmark configurations. J. Hymenopt. Res. 2016, 52. [CrossRef]

20. Charistos, L.; Hatjina, F.; Bouga, M.; Mladenovic, M.; Maistros, A.D. Morphological discrimination of Greek honey bee populations based on geometric morphometrics analysis of wing shape. J. Apic. Sci. 2014, 58, 75-84. [CrossRef]

21. Kandemir, İ.; Özkan, A.; Fuchs, S. Reevaluation of honeybee (Apis mellifera) microtaxonomy: A geometric morphometric approach. Apidologie 2011, 42, 618. [CrossRef]

22. Miguel, I.; Baylac, M.; Iriondo, M.; Manzano, C.; Garnery, L.; Estonba, A. Both geometric morphometric and microsatellite data consistently support the differentiation of the Apis mellifera $\mathrm{M}$ evolutionary branch. Apidologie 2011, 42, 150-161. [CrossRef]

23. Ruttner, F. Biogeography and Taxonomy of Honeybees; Springer Verlag: Berlin, Germany, 1988.

24. Bouga, M.; Alaux, C.; Bienkowska, M.; Büchler, R.; Carreck, N.L.; Cauia, E.; Chlebo, R.; Dahle, B.; Dall'Olio, R.; De la Rúa, P. A review of methods for discrimination of honey bee populations as applied to European beekeeping. J. Apic. Res. 2011, 50, 51-84. [CrossRef]

25. Arias, M.C.; Rinderer, T.E.; Sheppard, W.S. Further characterization of honey bees from the Iberian Peninsula by allozyme, morphometric and mtDNA haplotype analyses. J. Apic. Res. 2006, 45, 188-196. [CrossRef]

26. Chapman, N.C.; Harpur, B.A.; Lim, J.; Rinderer, T.E.; Allsopp, M.H.; Zayed, A.; Oldroyd, B.P. A SNP test to identify Africanized honeybees via proportion of 'African'ancestry. Mol. Ecol. Resour. 2015, 15, 1346-1355. [CrossRef] [PubMed]

27. Chen, C.; Liu, Z.; Pan, Q.; Chen, X.; Wang, H.; Guo, H.; Liu, S.; Lu, H.; Tian, S.; Li, R. Genomic analyses reveal demographic history and temperate adaptation of the newly discovered honey bee subspecies Apis mellifera sinisxinyuan n. ssp. Mol. Bio. Evol. 2016, 33, 1337-1348. [CrossRef] [PubMed]

28. Meixner, M.D.; Leta, M.A.; Koeniger, N.; Fuchs, S. The honey bees of Ethiopia represent a new subspecies of Apis mellifera-Apis mellifera simensis n. ssp. Apidologie 2011, 42, 425-437. [CrossRef]

29. Sheppard, W.S.; Meixner, M.D. Apis mellifera pomonella, a new honey bee subspecies from Central Asia. Apidologie 2003, 34, 367-375. [CrossRef]

30. Pinto, M.A.; Rubink, W.L.; Patton, J.C.; Coulson, R.N.; Johnston, J.S. Africanization in the United States: Replacement of feral European honeybees (Apis mellifera L.) by an African hybrid swarm. Genetics 2005, 170, 1653-1665. [CrossRef]

31. Daly, H.V.; Balling, S.S. Identification of Africanized honeybees in the Western Hemisphere by discriminant analysis. J. Kansas Entomol. Soc. 1978, 857-869.

32. Franck, P.; Garnery, L.; Solignac, M.; Cornuet, J.M. The origin of west European subspecies of honeybees (Apis mellifera): New insights from microsatellite and mitochondrial data. Evolution 1998, 52, 1119-1134.

33. Wallberg, A.; Han, F.; Wellhagen, G.; Dahle, B.; Kawata, M.; Haddad, N.; Simões, Z.L.P.; Allsopp, M.H.; Kandemir, I.; De la Rúa, P. A worldwide survey of genome sequence variation provides insight into the evolutionary history of the honeybee Apis mellifera. Nat. Genet. 2014, 46, 1081. [CrossRef] [PubMed]

34. Whitfield, C.W.; Behura, S.K.; Berlocher, S.H.; Clark, A.G.; Johnston, J.S.; Sheppard, W.S.; Smith, D.R.; Suarez, A.V.; Weaver, D.; Tsutsui, N.D. Thrice out of Africa: Ancient and recent expansions of the honey bee, Apis mellifera. Science 2006, 314, 642-645. [CrossRef] [PubMed]

35. Chávez-Galarza, J.; Henriques, D.; Johnston, J.S.; Carneiro, M.; Rufino, J.; Patton, J.C.; Pinto, M.A. Revisiting the Iberian honey bee (Apis mellifera iberiensis) contact zone: Maternal and genome-wide nuclear variations provide support for secondary contact from historical refugia. Mol. Ecol. 2015, 24, 2973-2992. [CrossRef] [PubMed]

36. Cornuet, J.; Fresnaye, J. Biometrical study of honey bee populations from Spain and Portugal [Apis mellifica ibera]. Apidologie (France) 1989, 20, 93-101. [CrossRef]

37. Smith, D.; Glenn, T. Allozyme polymorphisms in Spanish honeybees (Apis mellifera iberica). J. Hered. 1995, 86, 12-16. [CrossRef]

38. Garnery, L.; Mosshine, E.; Oldroyd, B.; Cornuet, J. Mitochondrial DNA variation in Moroccan and Spanish honey bee populations. Mol. Ecol. 1995, 4, 465-472. [CrossRef]

39. Miguel, I.; Iriondo, M.; Garnery, L.; Sheppard, W.S.; Estonba, A. Gene flow within the M evolutionary lineage of Apis mellifera: Role of the Pyrenees, isolation by distance and post-glacial re-colonization routes in the western Europe. Apidologie 2007, 38, 141-155. [CrossRef] 
40. Cánovas, F.; De la Rúa, P.; Serrano, J.; Galián, J. Geographical patterns of mitochondrial DNA variation in Apis mellifera iberiensis (Hymenoptera: Apidae). J. Zool. Syst. Evol. Res. 2008, 46, 24-30. [CrossRef]

41. Pinto, M.A.; Henriques, D.; Neto, M.; Guedes, H.; Muñoz, I.; Azevedo, J.C.; De la Rúa, P. Maternal diversity patterns of Ibero-Atlantic populations reveal further complexity of Iberian honeybees. Apidologie 2013, 44, 430-439. [CrossRef]

42. Pinto, M.A.; Muñoz, I.; Chávez-Galarza, J.; De la Rúa, P. The Atlantic side of the Iberian Peninsula: A hot-spot of novel African honey bee maternal diversity. Apidologie 2012, 43, 663-673. [CrossRef]

43. Smith, D.; Palopoli, M.; Taylor, B.; Garnery, L.; Cornuet, J.-M.; Solignac, M.; Brown, W. Geographical overlap of two mitochondrial genomes in Spanish honeybees (Apis mellifera iberica). J. Hered. 1991, 82, 96-100. [CrossRef] [PubMed]

44. De la Rúa, P.; Galián, J.; Serrano, J.; Moritz, R.F. Genetic structure and distinctness of Apis mellifera L. populations from the Canary Islands. Mol. Ecol. 2001, 10, 1733-1742. [CrossRef] [PubMed]

45. De la Rúa, P.; Galián, J.; Serrano, J.; Hernández-García, R.; Jiménez, Y. Biodiversity of Apis mellifera iberica (Hymenoptera: Apidae) from northeastern Spain assessed by mitochondrial analysis. Insect Syst. Evol. 2005, 36, 21-28. [CrossRef]

46. Garnery, L.; Franck, P.; Baudry, E.; Vautrin, D.; Cornuet, J.-M.; Solignac, M. Genetic diversity of the west European honey bee (Apis mellifera mellifera and A. m. iberica) I. Mitochondrial DNA. Genet. Sel. Evol. 1998, 30, S31. [CrossRef]

47. Henriques, D.; Chávez-Galarza, J.; Quaresma, A.; Neves, C.J.; Lopes, A.R.; Costa, C.; Costa, F.O.; Rufino, J.; Pinto, M.A. From the popular tRNA leu-COX2 intergenic region to the mitogenome: Insights from diverse honey bee populations of Europe and North Africa. Apidologie 2019, 50, 215-229. [CrossRef]

48. Chávez-Galarza, J.; Garnery, L.; Henriques, D.; Neves, C.J.; Loucif-Ayad, W.; Jonhston, J.S.; Pinto, M.A. Mitochondrial DNA variation of Apis mellifera iberiensis: Further insights from a large-scale study using sequence data of the tRNA leu-cox2 intergenic region. Apidologie 2017, 48, 533-544. [CrossRef]

49. Garnery, L.; Franck, P.; Baudry, E.; Vautrin, D.; Cornuet, J.-M.; Solignac, M. Genetic diversity of the west European honey bee (Apis mellifera mellifera and A. m. iberica) II. Microsatellite loci. Genet. Sel. Evol. 1998, 30, S49. [CrossRef]

50. De la Rúa, P.; Galián, J.; Serrano, J.; Moritz, R. Microsatellite analysis of non-migratory colonies of Apis mellifera iberica from south-eastern Spain. J. Zool. Syst. Evol. Res. 2002, 40, 164-168. [CrossRef]

51. Cánovas, F.; De la Rúa, P.; Serrano, J.; Galián, J. Microsatellite variability reveals beekeeping influences on Iberian honeybee populations. Apidologie 2011, 42, 235-251. [CrossRef]

52. Chávez-Galarza, J.; Henriques, D.; Johnston, J.S.; Azevedo, J.C.; Patton, J.C.; Muñoz, I.; De la Rúa, P.; Pinto, M.A. Signatures of selection in the Iberian honey bee (Apis mellifera iberiensis) revealed by a genome scan analysis of single nucleotide polymorphisms. Mol. Ecol. 2013, 22, 5890-5907. [CrossRef]

53. Henriques, D.; Wallberg, A.; Chávez-Galarza, J.; Johnston, J.S.; Webster, M.T.; Pinto, M.A. Whole genome SNP-associated signatures of local adaptation in honeybees of the Iberian Peninsula. Sci. Rep. 2018, 8, 11145. [CrossRef] [PubMed]

54. Dworkin, I.; Gibson, G. Epidermal growth factor receptor and transforming growth factor- $\beta$ signaling contributes to variation for wing shape in Drosophila melanogaster. Genetics 2006, 173, 1417-1431. [CrossRef]

55. Dujardin, J.-P. Morphometrics applied to medical entomology. Infect. Genet. Evol. 2008, 8, 875-890. [CrossRef] [PubMed]

56. Abbasi, R. Sexual dimorphism in the wing morphology of social vespid wasps-A case study on the genus Polistes Latreille using geometric morphometrics: (Hymenoptera: Vespidae). Zool. Middle East 2009, 47, 83-92. [CrossRef]

57. Pretorius, E. Using geometric morphometrics to investigate wing dimorphism in males and females of Hymenoptera-A case study based on the genus Tachysphex Kohl (Hymenoptera: Sphecidae: Larrinae). Aust. J. Ent. 2005, 44, 113-121. [CrossRef]

58. Benítez, H.A.; Bravi, R.; Parra, L.E.; Sanzana, M.-J.; Sepúlveda-Zúñiga, E. Allometric and non-allometric patterns in sexual dimorphism discrimination of wing shape in Ophion intricatus: Might two male morphotypes coexist? J. Insect Sci. 2013, 13, 143. [CrossRef]

59. Stubblefield, J.W.; Seger, J. Sexual Dimorphism in the Hymenoptera; Cambridge University Press: Cambridge, UK, 1994; pp. 71-103. 
60. Casteel, D.B.; Phillips, E.F. Comparative variability of drones and workers of the honey bee. Biol. Bull. 1903, 6, 18-37. [CrossRef]

61. Rohlf, F. tpsUtil version 1.44. Department of Ecology and Evolution, State University of New York at Stony Brook. Available online: https://life.bio.sunysb.edu/morph/ (accessed on 10 November 2016).

62. Rohlf, F.J. TPSdig,v.2.17. State University of New York at Stony Brook. Available online: https://life.bio. sunysb.edu/morph/ (accessed on 10 November 2016).

63. Klingenberg, C.P. MorphoJ: An integrated software package for geometric morphometrics. Mol. Ecol. Resour. 2011, 11, 353-357. [CrossRef]

64. Bookstein, F. Morphometric Tools for Landmark Data: Geometry and Biology; Cambridge Univ. Press: Cambridge, UK, 1991.

65. R Core Team. A Language and Environment for Statistical Computing; R Foundation for Statistical Computing: Vienna, Austria, 2013; Available online: http://www.R-project.org (accessed on 10 September 2019).

66. Jombart, T. adegenet: A R package for the multivariate analysis of genetic markers. Bioinformatics 2008, 24, 1403-1405. [CrossRef]

67. Dray, S.; Dufour, A.-B. The ade4 package: Implementing the duality diagram for ecologists. J. Stat. Softw. 2007, 22, 1-20. [CrossRef]

68. Moran, P.A. Notes on continuous stochastic phenomena. Biometrika 1950, 37, 17-23. [CrossRef] [PubMed]

69. Jombart, T.; Devillard, S.; Dufour, A.-B.; Pontier, D. Revealing cryptic spatial patterns in genetic variability by a new multivariate method. Heredity 2008, 101, 92. [CrossRef] [PubMed]

70. Wells, C.; Munn, A.; Woodworth, C. Geomorphic morphometric differences between populations of Speyeria diana (Lepidoptera: Nymphalidae). Fla. Entomol. 2018, 101, 195-203. [CrossRef]

71. Carvajal, T.M.; Hernandez, L.F.T.; Ho, H.T.; Cuenca, M.G.; Orantia, B.M.C.; Estrada, C.R.; Viacrusis, K.M.; Amalin, D.M.; Watanabe, K. Spatial analysis of wing geometry in dengue vector mosquito, Aedes aegypti (L.)(Diptera: Culicidae), populations in Metropolitan Manila, Philippines. J. Vector Borne Dis. 2016, 53, 127.

72. Krtinić, B.; Francuski, L.; Ludoški, J.; Milankov, V. Integrative approach revealed contrasting pattern of spatial structuring within urban and rural biotypes of Culex pipiens. J. Appl. Entomol. 2016, 140, 757-774. [CrossRef]

73. Francuski, L.; Milankov, V.; Ludoški, J.; Krtinić, B.; Lundström, J.O.; Kemenesi, G.; Ferenc, J. Genetic and phenotypic variation in central and northern European populations of Aedes (Aedimorphus) vexans (Meigen, 1830)(Diptera, Culicidae). J. Vector Ecol. 2016, 41, 160-171. [CrossRef]

74. Cardini, A.; Jansson, A.U.; Elton, S. A geometric morphometric approach to the study of ecogeographical and clinal variation in vervet monkeys. J. Biogeogr. 2007, 34, 1663-1678. [CrossRef]

75. Hernández-Romero, P.C.; Guerrero, J.A.; Valdespino, C. Morphological variability of the cranium of Lontra longicaudis (Carnivora: Mustelidae): A morphometric and geographic analysis. Zool. Stud. 2015, 54, 50. [CrossRef]

76. Combey, R.; Teixeira, J.S.G.; Bonatti, V.; Kwapong, P.; Francoy, T.M. Geometric morphometrics reveals morphological differentiation within four African stingless bee species. Ann. Bio. Res. 2013, 4, 93-103.

77. Francoy, T.M.; Grassi, M.L.; Imperatriz-Fonseca, V.L.; de Jesús May-Itzá, W.; Quezada-Euán, J.J.G. Geometric morphometrics of the wing as a tool for assigning genetic lineages and geographic origin to Melipona beecheii (Hymenoptera: Meliponini). Apidologie 2011, 42, 499. [CrossRef]

78. Chiari, Y.; Hyseni, C.; Fritts, T.H.; Glaberman, S.; Marquez, C.; Gibbs, J.P.; Claude, J.; Caccone, A. Morphometrics parallel genetics in a newly discovered and endangered taxon of Galápagos tortoise. PLoS ONE 2009, 4, e6272. [CrossRef] [PubMed]

79. Carreira, G.P.; Shaw, P.W.; Gonçalves, J.M.; McKeown, N.J. Congruent molecular and morphological diversity of Macaronesian limpets: Insights into eco-evolutionary forces and tools for conservation. Front. Mar. Sci. 2017, 4, 75. [CrossRef]

80. Garnier, S.; Magniez-Jannin, F.; Rasplus, J.Y.; Alibert, P. When morphometry meets genetics: Inferring the phylogeography of Carabus solieri using Fourier analyses of pronotum and male genitalia. J. Evol. Biol. 2005, 18, 269-280. [CrossRef] [PubMed]

81. Lorenz, C.; Patané, J.S.; Suesdek, L. Morphogenetic characterisation, date of divergence, and evolutionary relationships of malaria vectors Anopheles cruzii and Anopheles homunculus. Infect. Genet. Evol. 2015, 35, 144-152. [CrossRef] 
82. De Oliveira, L.R.; Hoffman, J.I.; Hingst-Zaher, E.; Majluf, P.; Muelbert, M.M.; Morgante, J.S.; Amos, W. Morphological and genetic evidence for two evolutionarily significant units (ESUs) in the South American fur seal, Arctocephalus gazella. Conserv. Genet. 2008, 9, 1451-1466. [CrossRef]

83. Camara, M.; Caro-Riano, H.; Ravel, S.; Dujardin, J.-P.; Hervouet, J.-p.; De Meeüs, T.; Kagbadouno, M.S.; Bouyer, J.; Solano, P. Genetic and morphometric evidence for population isolation of Glossina palpalis gambiensis (Diptera: Glossinidae) on the Loos islands, Guinea. J. Med. Entomol. 2006, 43, 853-860. [CrossRef]

(C) 2020 by the authors. Licensee MDPI, Basel, Switzerland. This article is an open access article distributed under the terms and conditions of the Creative Commons Attribution (CC BY) license (http://creativecommons.org/licenses/by/4.0/). 